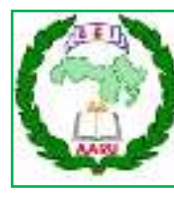

Arab Univ. J. Agric. Sci., Ain Shams Univ., Cairo, Egypt

29(1), 459 - 469, 2021

Website: http://ajs.journals.ekb.eg

DOI: 10.21608/ajs.2021.46495.1278

\title{
Impact of Organic Fertilizers Derived from Banana and Orange Peels on Tomato plant Quality
}

\author{
Mona I Nossier \\ Soils Dept, Fac of Agric, Ain Shams Univ, P.O. Box 68-Hadayek Shoubra 11241, \\ Cairo, Egypt \\ *Corresponding author: mona nossier@agr.asu.edu.eg
}

Received 15 October, 2020

Accepted 27 January, 2021

\begin{abstract}
The main objective of this research is to promote the reuse of wastes resulting from different manufacturing processes such as fruit peels (e.g. banana and orange peels) as substitutes (at least partially) of mineral fertilizers. This might have positive effects in maintaining human health and reducing environmental pollution. Moreover, to compare the use of these wastes with commercial organic fertilizer i.e., compost made by Nile Company to meet the needs of tomato plants from nitrogen $(\mathrm{N})$ and potassium (K) elements. To achieve the goal, two experiments were conducted. The first was an incubation experiment, which was designed to compare the organic fertilizer compost of Nile Company and the powdered banana and orange peels. The second was a field experiment achieved at the Faculty of Agriculture, Ain Shams University. Obtained results of the incubation experiment showed increases in nitrogen content by 16 to $31 \%$ and potassium by 12 to $24 \%$ due to using grinded banana and orange peels as compared to the compost treatment. Moreover, in the field experiment the concentration of nitrogen $(\mathrm{N})$ and potassium (K) at different plant growth stages whether in soil or plant did not differ significantly between soil plots fertilized with mineral fertilization and those fertilized with banana and orange ones. On contrary, potassium concentration was found higher in the soil fertilized with organic fertilization than that fertilized with
\end{abstract}

mineral fertilization. It has also been found to us that there are no clear significant differences between tomato fruits resulting from mineral fertilization of the ground and those that were fertilized by the mixture of banana and orange peels in terms of the ratio of nitrogen and potassium, weight, size and density of the fruit and other characteristics except for the total salts percentage, which was less Fruits fertilized with a mixture of banana and orange peels.

Keywords: Banana and Orange Peels; Compost; Tomatoes.

\section{Introduction}

There are two basic types of fertilization, either organic fertilization or mineral fertilization, and each of them has its advantages and disadvantages, but the basic judgment for us in choosing between them is the health of the human being and the animal feeding on these plants. Therefore, we must be keen on fertilizing the soil in a way that includes us getting the plant, all its needs of plant nutrients, but in a safe manner for human and animal health.

Due to the increasing population in the world, the amount of wastes from food residues increases, and therefore there are tons of these wastes produced annually, which constitutes a burden on countries in how to get rid of these solid and liquid wastes and these causing environmental problems (Divina, 2016). 
World Bank report estimated that between 2009 and 2030, food demands will increase by $50 \%$ as the population grows, and consequently will require greater food production and processing. Unfortunately, not all food produced in the fields end up in the tables to feed the population, but a great amount eventually becomes food waste (Menas et al 2011).

Fertilizers are either inorganic or organic material of natural or synthetic origin that is added to a soil in order to supply one or more plant nutrients that are essential to the growth of plants. Fruits contain high amounts of antioxidants that are beneficial to human health in many ways (Faria et al 2006; Hiral et al (2016).

Most plants need a certain amount of these top three macronutrients: nitrogen, phosphorus, and potassium. Some plants are more needful of nitrogen, while others are more needful of phosphorus, and still others need a higher level of potassium (Kristi, 2018). Fruits peels contain the most incredible nutrients in the world. There are many health benefits of both orange and banana peels that are unknown (Iram, 2015).Banana peels; it contains also manganese which helps in photosynthesis process; sodium, which helps in the movement of water between cells; especially some potassium loving plants need. and magnesium and sulfur, both of which are helpful in the formation of chlorophyll, also contain calcium, which helps plants to take up more nitrogen (Kristi, 2018). Banana peels are particularly effective for use as a natural fertilizer. Also banana and orange peels can add nutrients to the soil as they decompose. They rot quickly if burying them, offering rich stores for vital nutrients to the soil, including, magnesium, calcium, phosphorus, sulfur, potassium, and sodium. In addition, dried and grinded peels can be used as mulch, or applying directly to planting areas (Caryn, 2018). Also, banana peels are a fantastic source of organic potassium and loads high in potassium than even wood ash (Kristi, 2018).

\section{Materials and Methods}

This study was carried out to study the effect of dried and grinded banana and orange peels treatments (without converting them to compost) on the concentration of $\mathrm{N}$ and $\mathrm{K}$ by tomato plants at different growth stages, and how this treatments affect the quality of its fruit. To achieve this, two experiments were conducted. The first was a laboratory incubation experiment, and the second was a field experiment.

\subsection{Incubation experiment}

This experiment was conducted mainly to compare the effect of processed plant compost (Nile Company) and the effect of dried and grinded banana and orange peels on the availability of $\mathrm{N}$ and $\mathrm{K}$ in soil at successive time intervals. The Nile Company Compost was subjected to elemental analyses and the data are given in (Table 1).

Also some analyses were conducted on the dried and grinded peels of bananas and oranges. The analyses results are shown in (Table 2).

Table 1. Some chemical analyses of the Nile Company compost

\begin{tabular}{|c|c|c|c|c|c|c|c|}
\hline Element & $\mathbf{N}$ & $\mathbf{P}$ & $\mathbf{K}$ & $\mathbf{F e}$ & $\mathbf{Z n}$ & $\mathbf{M n}$ & \% O.C \\
\hline $\begin{array}{c}\text { Concentra- } \\
\text { tion (ppm) }\end{array}$ & 17.2 & 3.6 & 13.9 & 1500 & 54.4 & 140 & 28.5 \\
\hline
\end{tabular}

Table 2. Some chemical analyses of the studied fruits peels

\begin{tabular}{|c|c|c|c|c|c|c|c|}
\hline $\begin{array}{c}\text { Element } \\
\text { conc. }(\mathbf{p p m})\end{array}$ & $\mathbf{N}$ & $\mathbf{P}$ & $\mathbf{K}$ & $\mathbf{F e}$ & $\mathbf{Z n}$ & $\mathbf{M n}$ & $\begin{array}{c}\boldsymbol{\%} \mathbf{O} \\
\mathbf{C}\end{array}$ \\
\hline Orange peels & 9.40 & 2.33 & 7.90 & 1.15 & 0.12 & 0.04 & 46.24 \\
\hline Banana peels & 11.40 & 2.89 & 24.40 & 1.18 & 0.06 & 0.50 & 37.00 \\
\hline
\end{tabular}

A sand washed medium was prepared and $300 \mathrm{~g}$ of it was put in a pot and mixed thoroughly with a given treatment as follows: 


\section{Impact of Organic Fertilizers Derived from Banana and Orange Peels on Tomato plant Quality}

A- $40 \mathrm{~g}$ of Nile Company compost.

B- $20 \mathrm{~g}$ of banana and orange peels.

C- $40 \mathrm{~g}$ of banana and orange peels.

Each treatment was replicated three times.

Samples from each pot were taken at successive intervals (i.e. zero, one, two, four and eight weeks). Available $\mathrm{N}$ and $\mathrm{K}$ concentrations were then determined immediately after each sampling time.

\subsection{Field experiment}

A field experiment was conducted at the Faculty of Agriculture, Ain Shams University. Some physical and chemical analyses of the studied soil site are shown in (Table 3).

Table 3. Some physical and chemical analyses of the studied soil sample

\begin{tabular}{|c|c|}
\hline \multicolumn{2}{|c|}{ Particle size distribution, $\%$} \\
\hline C. Sand & 14.5 \\
\hline F. Sand & 19.5 \\
\hline Silt & 33.7 \\
\hline Clay & 32.3 \\
\hline Texture class & Silt Clay \\
\hline $\begin{array}{c}\text { pH (1:2.5 soil: w } \\
\text { suspension) }\end{array}$ & 7.9 \\
\hline $\mathrm{EC}_{\mathrm{e}}, \mathrm{dS} \mathrm{m}^{-1}$ & 4.4 \\
\hline \multicolumn{2}{|c|}{ Soluble cations, meq $\mathrm{L}^{-1}$} \\
\hline $\mathrm{Ca}^{2+}$ & 13.4 \\
\hline $\mathrm{Mg}^{2+}$ & 6.6 \\
\hline $\mathrm{Na}^{+}$ & 23.3 \\
\hline $\mathrm{K}^{+}$ & 0.7 \\
\hline \multicolumn{2}{|c|}{ Soluble anions, meq $\mathrm{L}^{-1}$} \\
\hline $\mathrm{CO}_{3}^{2-}$ & 0 \\
\hline $\mathrm{HCO}_{3}^{-}$ & 1.2 \\
\hline $\mathrm{Cl}^{-}$ & 40.1 \\
\hline $\mathrm{SO}_{4}^{2-}$ & 2.7 \\
\hline \multicolumn{2}{|c|}{ Concerned available elements, ppm } \\
\hline $\mathrm{N}$ & 50 \\
\hline $\mathrm{P}$ & 0.9 \\
\hline $\mathrm{K}$ & 120 \\
\hline
\end{tabular}

Before planting of tomato seedlings, the soil was fertilized with both composting animal waste fertilizer $\left(80 \mathrm{~kg} / 32 \mathrm{~m}^{2}\right)$ and super phosphate fertilizers $\left(16 \mathrm{~kg} / 32 \mathrm{~m}^{2}\right)$. Afterwards, the experimental soil was divided into four agricultural lines, the area of the line $(8 \mathrm{~m} * 70 \mathrm{~cm})$, the distance between lines $30 \mathrm{~cm}$ and the distance between plants $10 \mathrm{~cm}$. The first and $\mathrm{sec}-$ ond lines were fertilized with mineral fertilizers in the usual quantities and considered as control treatment. The third and fourth lines were fertilized with grinded banana and orange peels (Table 4), in quantities that meet the nutrient needs of the plant based on the result of the above analysis (Table 2).

Two extracts from banana peels were collected and their mineral contents was determined and given in (Table 5).

These extracts were used to spray tomato plants before and during the flowering stages directly. Soil and plant samples were collected during the physiological growth stages of tomato plant and nitrogen, phosphorus and potassium were determined at each stage.

\subsection{Methods of analysis}

\subsubsection{Soil analysis}

Soil samples were collected before plant cultivation, The abovementioned soil were sampled at a depth of 0 to $20 \mathrm{~cm}$ air dried, ground and sieved through a $2 \mathrm{~mm}$ sieve, finally preserved for the following analysis according to Jackson (1973) and Baruah and Barthakur (1997).

Soil mechanical analysis was carried out by the pipette method using sodium hexametaphosphate as a dispersing agent.

The soil available $\mathrm{N}, \mathrm{P}$ and $\mathrm{k}$ were extracted by $1 \% \mathrm{~K}_{2} \mathrm{SO}_{4}, 0.5 \mathrm{~N} \mathrm{NaHCO}_{3}$, and $1 \mathrm{~N}$ $\mathrm{NH}_{4} \mathrm{OAc}$ (pH 7.0), respectively (Black, 1965; Jackson, 1973).

\subsubsection{Plant analysis}

The plant samples dried at $70^{\circ} \mathrm{C}$ were wet digested with a mixture of $\mathrm{H}_{2} \mathrm{SO}_{4}$ and $\mathrm{H}_{2} \mathrm{O}_{2}$ according to Cottenie et al (1982). 
- Total nitrogen content in plant was determined by micro kjeldahl method using $5 \%$ boric acid and $40 \% \mathrm{NaOH}$ as described by Black et al (1965).

- Total potassium was determined using Flame photometer (Jackson, 1973).

- Total phosphorus was determined using spectrophotometer.

- Lycopene was determined using rapid extraction of lycopene and $\beta$-carotene from reconstituted tomato paste and pink grapefruit homogenates (Sadler et al 1990)

- Anti-oxidant capacity of flavonoids from Licanialicaniaeflora (Bors, 1992; Braca, 2002).
A total soluble solid of the tomato juice was measured by the method described by Tigchelaar (1986).

- The $\mathrm{pH}$ of the tomato juice was determined by the method described by Rangana (1979).

\subsubsection{Statistics program for statistical anal- ysis (T- test in pairs- SAS- test)}

The obtained data were statistically analysed using SAS software package. The means that were significant were separated using Duncan's multiple range test at $\mathrm{P}=0.05$ (SAS, 2006).

Table 4. Rates of mineral and organic fertilizers added during tomato growth according to plant's needs

\begin{tabular}{|c|c|c|c|}
\hline $\begin{array}{c}\text { Time } \\
\text { (week) }\end{array}$ & & Control soil & Treated soil \\
\hline \multirow{2}{*}{1} & \multirow{6}{*}{$\begin{array}{l}\text { vegetable } \\
\text { growth }\end{array}$} & \multicolumn{2}{|c|}{$16 \mathrm{~kg} / 32 \mathrm{~m}^{2}$ super phosphate $+80 \mathrm{~kg} / 32 \mathrm{~m}^{2}$ compost fertilizer } \\
\hline & & & $500 \mathrm{~g}$ banana $+1000 \mathrm{~g}$ orange dry peels \\
\hline 2 & & \multicolumn{2}{|l|}{ Agriculture date } \\
\hline \multirow{2}{*}{3} & & & $200 \mathrm{~g}$ banana $+1000 \mathrm{~g}$ orange dry peels \\
\hline & & \multicolumn{2}{|c|}{$16 \mathrm{~kg} / 32 \mathrm{~m}^{2}$ super phosphate } \\
\hline 4 & & $1.5 \mathrm{~kg} / 16 \mathrm{~m}^{2}$ urea & \\
\hline \multirow{2}{*}{5} & \multirow{4}{*}{$\begin{array}{l}\text { Floral } \\
\text { growth }\end{array}$} & \multicolumn{2}{|c|}{$16 \mathrm{~kg} / 32 \mathrm{~m}^{2}$ super phosphate } \\
\hline & & $1.5 \mathrm{~kg} / 16 \mathrm{~m}^{2}$ urea & \\
\hline 6 & & & $\begin{array}{l}300 \mathrm{~g} \text { banana }+300 \mathrm{~g} \text { orange dry peels }+ \text { extract solution from } \\
500 \mathrm{~g} \text { banana peels } / 3 \mathrm{~L} \text { water }\end{array}$ \\
\hline 7 & & & spry extract solution from $500 \mathrm{~g}$ banana fresh peels $/ 3 \mathrm{~L}$ water \\
\hline 8 & \multirow{3}{*}{$\begin{array}{l}\text { Fruit } \\
\text { growth }\end{array}$} & & spry extract solution from $1000 \mathrm{~g}$ banana fresh peels/ 3L water \\
\hline 9 & & & spry extract solution from $1000 \mathrm{~g}$ banana fresh peels/3L water \\
\hline 13 & & $\left|\begin{array}{l}\left(1.5 \mathrm{~kg} \mathrm{Ca}\left(\mathrm{NO}_{3}\right)_{2}+\right. \\
\left.800 \mathrm{~g} \mathrm{~K}_{2} \mathrm{SO}_{4}\right) / 16 \mathrm{~m}^{2}\end{array}\right|$ & \\
\hline
\end{tabular}

Table 5. Some chemical analyses of the two extracts from banana peels

\begin{tabular}{|l|c|c|c|c|c|c|}
\hline Element & N & P & K & Fe & Zn & Mn \\
\hline B1 (0.5kg banana peels/ 3L water) & 16.3 & 1.4 & 2.5 & 0.299 & 0.469 & 0.243 \\
\hline B2 (1.0kg banana peels/ 3L water) & 23.4 & 2.6 & 4.1 & 0.681 & 0.581 & 0.396 \\
\hline
\end{tabular}




\section{Impact of Organic Fertilizers Derived from Banana and Orange Peels on Tomato plant Quality}

\section{Results}

\subsection{Incubation experiment}

In this experiment, a decrease in the percentage of nitrogen and potassium was observed with the passage of time, and this was due to the activity of microorganisms on the analysis of these residues (compost fertilizer banana and orange peels), but it was clear that there was a significant increase in the ratio of nitrogen and potassium facilitated in the soil treated with banana and orange peel compared to the soil that treated with compost (Tables 6 and 7).

\subsection{Field experiment}

\subsubsection{Results of soil analysis}

It was observed that there was an insignificant increase in the ratio of nitrogen and potassium in the soil treated with banana and orange peels compared to the control treatment, while phosphorus was low compared to control in the vegetative growth phase, the ratio of nitrogen and potassium in the ground treated with banana and orange peel was observed increase while phosphorus was low compared to control treatment in the floral growth, it was observed that there was an insignificant increase in the ratio of potassium in the soil treated with banana and orange peels compared to the control, while the ratio of nitrogen not increased significantly but phosphorus was low compared to control in the fruit growth stage.

\subsubsection{Results of plant analysis}

The percentage of $\mathrm{N}, \mathrm{K}$ and $\mathrm{P}$ in the vegetative growth of tomato plant grown in the soil that treated by banana and orange peels was observed increase as compared to control treatment in the vegetative growth, The percentage of $\mathrm{N}, \mathrm{K}$ and $\mathrm{P}$ in the vegetative growth of tomato plant grown in the soil that treated by banana and orange peels was observed increase as compared to control treatment in the floral growth, for nitrogen, there was no significant difference between the two treatments in the fruit growth stage but gave higher values in potassium and phosphorus as compared to control treatment in the growth stage.

Table 6. Effect of fertilization with banana and orange peels on nitrogen availability compared to compost

\begin{tabular}{|c|c|c|c|c|c|}
\hline \multirow{2}{*}{ Time (week) } & $\mathbf{0}$ & $\mathbf{1}$ & $\mathbf{2}$ & $\mathbf{4}$ & $\mathbf{8}$ \\
\cline { 2 - 6 } Treatments & \multicolumn{5}{|c|}{$\mathbf{N}(\mathbf{p p m})$} \\
\hline Compost & $188.6 \mathrm{ABC}$ & $144 \mathrm{BDC}$ & $127.3 \mathrm{DES}$ & $110.3 \mathrm{DE}$ & $65.6 \mathrm{E}$ \\
\hline T 20 & $212.3 \mathrm{AB}$ & $123.3 \mathrm{DEC}$ & $205.6 \mathrm{AB}$ & $112 \mathrm{DEC}$ & $111 \mathrm{DE}$ \\
\hline T 40 & $238.3 \mathrm{~A}$ & $140 \mathrm{BDEC}$ & $243.6 \mathrm{~A}$ & $119.6 \mathrm{DEC}$ & $187.3 \mathrm{ABCD}$ \\
\hline
\end{tabular}

Means with the same letters are not significantly different.

T 20: $10 \mathrm{~g}$ orange peels $+10 \mathrm{~g}$ banana peels; $\mathrm{T} 40: 20 \mathrm{~g}$ orange peels $+20 \mathrm{~g}$ banana peels.

Table 7. Effect of fertilization with banana and orange peels on potassium availability compared to compost

\begin{tabular}{|c|c|c|c|c|c|}
\hline \multirow{2}{*}{ Time (week) } & $\mathbf{0}$ & $\mathbf{1}$ & $\mathbf{2}$ & $\mathbf{4}$ & $\mathbf{8}$ \\
\cline { 2 - 6 } Treatments & \multicolumn{5}{|c|}{ K (ppm) } \\
\hline Compost & $662.2 \mathrm{ED}$ & $530 \mathrm{EF}$ & $438.4 \mathrm{~F}$ & $805.5 \mathrm{BCD}$ & $618.7 \mathrm{E}$ \\
\hline T 20 & $673.3 \mathrm{ECD}$ & $601.3 \mathrm{E}$ & $562.8 \mathrm{EF}$ & $823.1 \mathrm{BC}$ & $810.9 \mathrm{BCD}$ \\
\hline T 40 & $873.5 \mathrm{~B}$ & $628.6 \mathrm{E}$ & $635.9 \mathrm{E}$ & $1030.3 \mathrm{~A}$ & $888.2 \mathrm{AB}$ \\
\hline
\end{tabular}

Means with the same letters are not significantly different.

T 20: $10 \mathrm{~g}$ orange peels $+10 \mathrm{~g}$ banana peels; $\mathrm{T} 40: 20 \mathrm{~g}$ orange peels $+20 \mathrm{~g}$ banana peels. 
Table 8. Effect of fertilization with banana and orange peels on the concentration of nitrogen, potassium and phosphorus as compared to control treatment

\begin{tabular}{|c|c|c|c|c|}
\hline Measurements and treatments & & $\begin{array}{c}\text { Means } \\
\text { values }\end{array}$ & $\begin{array}{c}\mathbf{T} \\
\text { Value }\end{array}$ & Pr $>(T)$ \\
\hline \multirow{2}{*}{ Vegetable growth stage $(\mathrm{N})$} & Control & 120.0 & \multirow[b]{2}{*}{1.80} & \multirow[b]{2}{*}{0.02} \\
\hline & Treatment & 193.0 & & \\
\hline \multirow{2}{*}{ Vegetable growth stage $(\mathrm{P})$} & Control & 2.4 & \multirow[b]{2}{*}{2.50} & \multirow[b]{2}{*}{0.12} \\
\hline & Treatment & 1.3 & & \\
\hline \multirow{2}{*}{ Vegetable growth stage $(\mathrm{K})$} & Control & 294.8 & \multirow[b]{2}{*}{0.90} & \multirow[b]{2}{*}{0.46} \\
\hline & Treatment & 339.5 & & \\
\hline \multirow{2}{*}{ Floral growth stage $(\mathrm{N})$} & Control & 162.0 & \multirow[b]{2}{*}{0.27} & \multirow[b]{2}{*}{0.81} \\
\hline & Treatment & 175.0 & & \\
\hline \multirow{2}{*}{ Floral growth stage $(\mathrm{P})$} & Control & 10.1 & \multirow[b]{2}{*}{1.25} & \multirow[b]{2}{*}{0.33} \\
\hline & Treatment & 6.2 & & \\
\hline \multirow{2}{*}{ Floral growth stage $(\mathrm{K})$} & Control & 372.6 & \multirow[b]{2}{*}{0.96} & \multirow[b]{2}{*}{0.43} \\
\hline & Treatment & 390.1 & & \\
\hline \multirow{2}{*}{ Fruit growth stage $(\mathrm{N})$} & Control & 123.5 & \multirow[b]{2}{*}{0.01} & \multirow[b]{2}{*}{0.99} \\
\hline & Treatment & 125.0 & & \\
\hline \multirow{2}{*}{ Fruit growth stage $(\mathrm{P})$} & Control & 2.8 & \multirow[b]{2}{*}{1.53} & \multirow[b]{2}{*}{0.26} \\
\hline & Treatment & 1.8 & & \\
\hline \multirow{2}{*}{ Fruit growth stage $(\mathrm{K})$} & Control & 169.0 & \multirow[b]{2}{*}{8.12} & \multirow[b]{2}{*}{0.01} \\
\hline & Treatment & 221.0 & & \\
\hline
\end{tabular}

Pr> (T) 0.05 not significant.

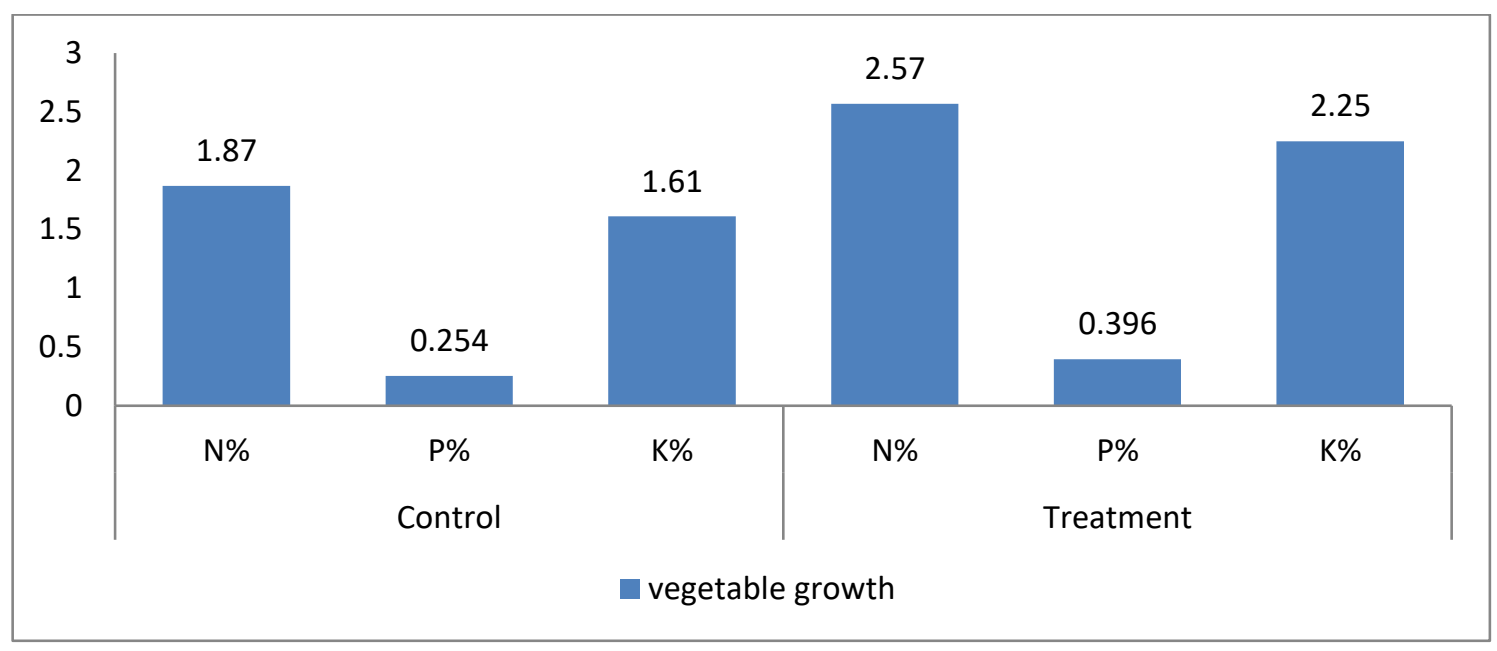

Fig 1. Effect of fertilization on banana and orange peels on the concentration of nitrogen, potassium and phosphorus as compared to control at the vegetative growth stage 


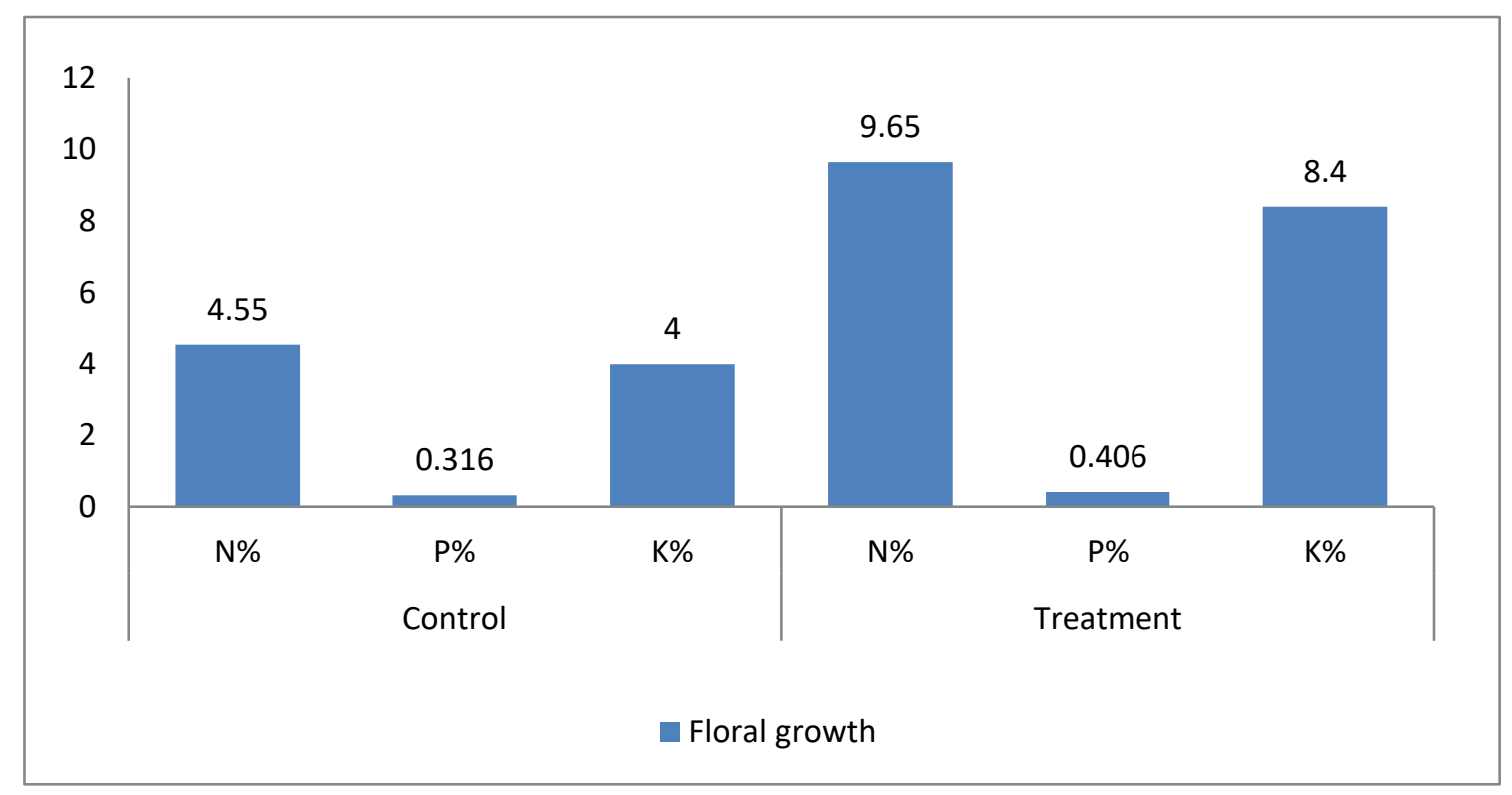

Fig 2. Effect of fertilization with banana and orange peels on the concentration of nitrogen, potassium and phosphorus as compared to control at floral growth stage

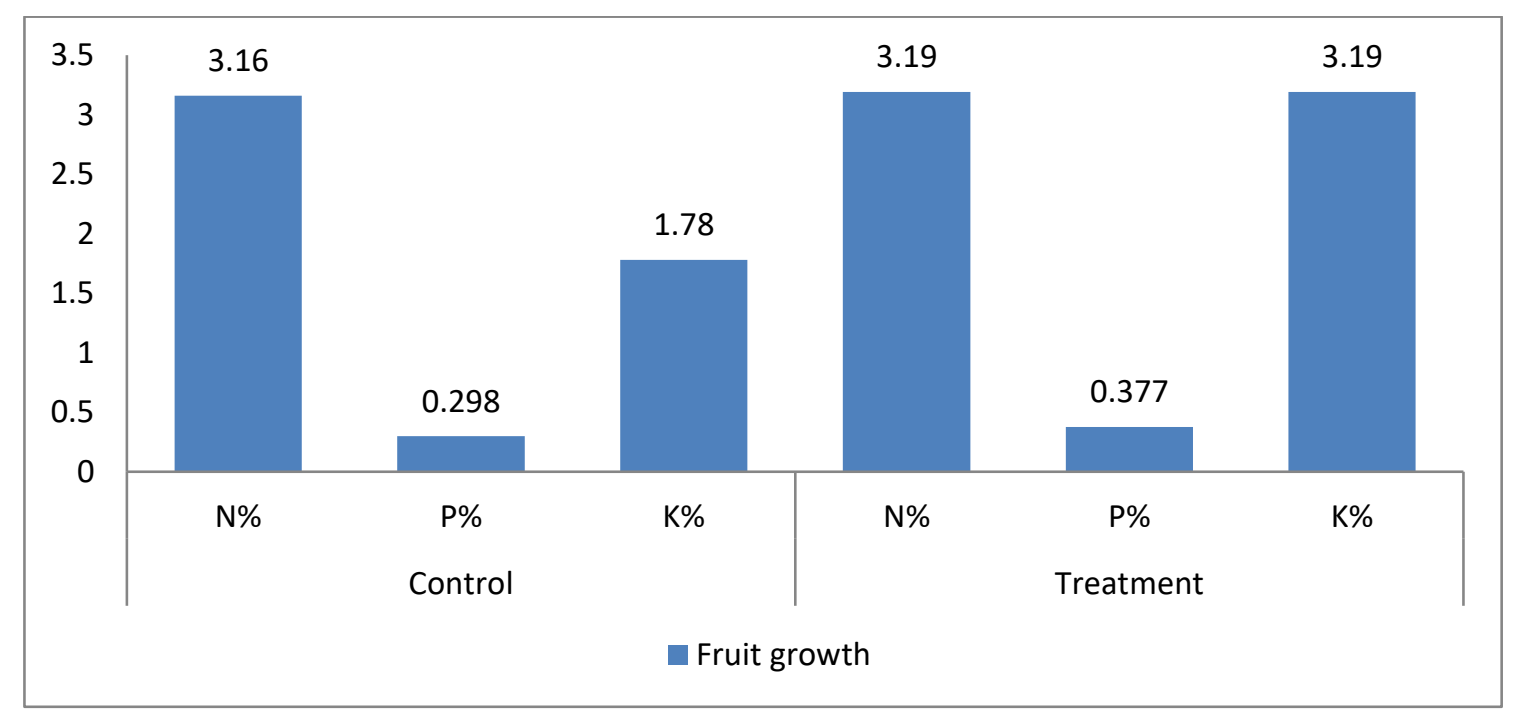

Fig 3. Effect of fertilization with banana and orange peels on the concentration of nitrogen, potassium and phosphorus as compared to control at the fruit growth stage

Table 9. Effect of banana and orange peels fertilization on the nutrients content of tomato fruits

\begin{tabular}{|c|c|c|}
\hline Element (\%) & Control & Treatment \\
\hline $\mathbf{N}$ & $3.5 \mathrm{a}$ & $2.66 \mathrm{ab}$ \\
\hline $\mathbf{P}$ & $0.439 \mathrm{a}$ & $0.443 \mathrm{a}$ \\
\hline $\mathbf{K}$ & $1.89 \mathrm{a}$ & $1.87 \mathrm{a}$ \\
\hline
\end{tabular}


Table 10. Effect of banana and orange peels fertilization on the quality of tomato fruits compared to control treatment

\begin{tabular}{|c|c|c|c|c|}
\hline Measurements and treatments & & $\begin{array}{c}\text { Mean } \\
\text { Values }\end{array}$ & $\begin{array}{c}\text { T } \\
\text { Value }\end{array}$ & $\operatorname{Pr}>(\mathbf{T})$ \\
\hline \multirow[b]{2}{*}{ Weight (g) } & Control & 81.2 & \multirow[b]{2}{*}{1.23} & \multirow[b]{2}{*}{0.29} \\
\hline & Treatment & 71.5 & & \\
\hline \multirow[b]{2}{*}{ Volume $\left(\mathrm{cm}^{3}\right)$} & Control & 52.4 & \multirow[b]{2}{*}{1.18} & \multirow[b]{2}{*}{0.31} \\
\hline & Treatment & 71.2 & & \\
\hline \multirow[b]{2}{*}{ Fruit Density $\left(\mathrm{g} / \mathrm{cm}^{3}\right)$} & Control & 0.89 & \multirow[b]{2}{*}{195} & \multirow[b]{2}{*}{0.12} \\
\hline & Treatment & 0.93 & & \\
\hline \multirow[b]{2}{*}{ Total Water content $(\%)$} & Control & 87.8 & \multirow[b]{2}{*}{2.14} & \multirow[b]{2}{*}{0.09} \\
\hline & Treatment & 86.3 & & \\
\hline \multirow[b]{2}{*}{ True Acidity $(\mathrm{pH})$} & Control & 4.1 & \multirow[b]{2}{*}{0.84} & \multirow[b]{2}{*}{0.44} \\
\hline & Treatment & 3.6 & & \\
\hline \multirow[b]{2}{*}{ TDS (mg/ l) } & Control & 3906.7 & \multirow[b]{2}{*}{8.32} & \multirow[b]{2}{*}{0.001} \\
\hline & Treatment & 3026.7 & & \\
\hline \multirow[b]{2}{*}{ Lycopene (mg/g fresh wt.) } & Control & 50.5 & \multirow[b]{2}{*}{0.13} & \multirow[b]{2}{*}{0.91} \\
\hline & Treatment & 50.3 & & \\
\hline \multirow[b]{2}{*}{ Anti-Oxidant Capacity } & Control & 55.9 & \multirow[b]{2}{*}{4.04} & \multirow[b]{2}{*}{0.015} \\
\hline & Treatment & 48.3 & & \\
\hline
\end{tabular}

Pr> (T) 0.05 not significantly

\subsubsection{Results of tomato plant analysis}

It is noted that there were no significant differences in the standards for the quality of tomato fruits between the treatment of banana and orange peel and control treatment except in the TDS $(\mathrm{mg} / \mathrm{L})$.

\section{Discussion}

Previous results obtained indicate that mineral fertilizers can be substituted with organic fertilizers resulting from the use of banana and orange peel where it was observed the convergence of the results obtained and the absence of any significant differences when fertilizing banana and orange scales or fertilization with the usual mineral fertilizer used, on the contrary, there was an increase in the potassium ratio at each stage of tomato plant growth when fertilizing with banana and orange peel.

It was also observed that there were no significant differences in the quality of the fruits of the tomato plant according to both methods in fertilization high in the quality of tomato fruits fertilized with banana and orange peel, especially in the proportion of total salts and acidity were less than the control.

The reason is that banana and orange peel is rich in many plant nutrients during its various stages of development. Several studies have confirmed the richness of fruits and vegetables with a variety of nutrients.

Both have been explained (Tsay et al 2004; Mercy et al 2014a), it has become common recently that use fruit and vegetable peels as fertilizer for the soil, as the efficiency and fertility of the soil have increased by using different formulations of organic fertilizers with fruit peels, as there has been an increase in the various types of microorganisms suitable for plant growth in the soil. It has been observed that the increase in the elemental content of the earth is due to the fact that these crusts are rich in elements necessary for the soil and plant growth.

Mercy et al (2014b) emphasized in their research that the fruit peels of banana, sweet lemon, orange and pomegranate are very rich in iron, potassium, zinc and many other elements that increase soil fertility and thus increase the growth and health of the plant. 


\section{Impact of Organic Fertilizers Derived from Banana and Orange Peels on Tomato plant Quality}

Hiral et al (2016) have confirmed in their research that the use of powdered fruit peels such as bananas, oranges, pomegranates, and others can be used as fertilizer for the ground, regulating the $\mathrm{pH}$ and supplementing some nutrients such as zinc, iron and calcium, and they emphasized that the use of these peels in fertilization does not require a high cost and thus it also helps in transferring waste into usable materials.

\section{Conclusion}

It can be conclude that the trend towards recycling of organic wastes such as peel fruits and vegetables and fertilizing the soil, where it was found that this method is easier to apply and does not take a long time or high cost as it has not any obstacles, not producing any smells, does not need to allocate specific places for the manufacturing and processing compared to the traditional compost or mineral fertilizer, (from the soil and back to the soil).The study recommend more detailed studies on the utilization of agricultural wastes (e.g. fruits peels) . In this concern, it is recommended to collect fruits peels from factories, drying, grinding and then add with the municipal fertilizer to the soil two weeks before planting. It is also preferable to calculate the plant needs of the nutrients and accordingly add the appropriate quantities of dried banana and orange peel to meet its needs.

\section{References}

Anhwange, BA (2008) Chemical Composition of Musa sapientum (Banana) Peels. J. Food Tech 6, 263-266.

Baruah, TC; Barthakur HP (1997) A Text Book of Analysis. (1stedn). Vikas Publishing House Pvt Ltd, New Delhi, India. pp. 334.

Black, CA (1965) Methods of soil analysis part II. American Society of Agronomy, Madison, Wisconsin, USA, pp. 374-399.

Bors, W; Saran, M; Elstner, E (1992) Screening for plant antioxidants. InPlant Toxin Analysis. Springer, pp 277- 295.
Braca, A, Sortino, C; Politi, M; Morelli, I; Mendez J (2002) Antioxidant activity of flavonoids from Licania licaniaeflora. J. Ethnopharmacology 79, 379- 381.

Caryn, (2018)Banana Peels \& Orange Peels in the Garden. Updated December 14, https://homeguides.sfgate.com/.

Cottenie, A; Verloo, M; Kiekens, L; Velgh, G and Camerlynech R (1982) Chemical Analysis of Plants and Soils. State Univ. Ghent, Belgium 63.

Divina, CC (2016) Scraps No More: Fruit Wastes for Benefits of Plants and Animals. Inter. J. Agric. Tech 12, 1535- 1545.

Faria, A; Calhau, C; Freitas, V; Mateus, N (2006) Procyanidins as antioxidants and tumor cell growth modulators. J. Agric. Food. Chem. Mar 22; 54(6), 2392-2397.

Hiral, JJ; Syed HS (2016) Study on Use of Fruit Peels Powder as a Fertilizer. Conference: Recent Advances in Environmental Sciences and Engineering, pp 1-4.

Iram, Z(2015) Health benefits of orange and banana peels. Updated: Friday, December 11, https://www.boldsky.com/.

Kristi, S (2018) Banana Peel Fertilizer Benefits and uses, June $16 \mathrm{https} / / /$ stonefamilyfarmstead.com/.

Menas, C; Adenso-Diaz, BB; Yurt, O (2011) The causes of food waste in the supplier retailer interface: Evidences from the UK and Spain. Resources, Conservation and Recycling 55, 648- 658.

Mercy, SS; Banu, M; Jenifer, I (2014) Application of different fruit peels formulations as a natural fertilizer for plant growth. Inter J Scientific \& Technology Research 3, 301-302.

Jackson, ML (1973) Soil Chemical Analysis. Prentice-Hall of India Private Limited, New Delhi, India.

Rangana, S (1979) Manual Analysis of Fruits and Vegetables Product. Tata McGraw-Hill Co. Ltd., New Delhi, pp 2- 95. 
Sadler, G; Davis, J; Dezman, D (1990) Rapid extraction of lycopene and carotene from reconstituted tomato paste and pink grapefruit homogenates. J. Food Sci 55, 1460- 1461.

SAS (2006) Statistical Analysis system, SAS Users Guide: Statistics. SAS institute inc. Editors, Cary, NC.
Tigchelaar, EC (1986) Tomato breeding. In: Basset MJ. Breeding vegetables Crops, pp 135- 171.

Tsay, TT; Wu, ST; Lin, YY (2004) Evaluation of Asteraceae plants for control of Meloidogyne incognita. J Nematol 36, 36- 41. 
مجلة اتحاد الجامعات العربية للعلوم الزراعية، جامعة عين شمس، القاهرة، مصر مجلد(29)، عدد(1)، 459 - 469، 2021

Website: http://ajs.journals.ekb.eg

DOI: 10.21608/ajs.2021.46495.1278

تأثير الأسمدة العضوية المشتقة من قثور البرتقال والموز على جودة نبات الطماطر

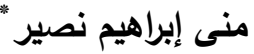 \\ قسم الآراضي - كلية الزراعة - جامعة عين شمس - ص.ب 68 - حدائق شبرا 11241 - القاهرة - مصر
}

*Corresponding author: mona nossier@agr.asu.edu.eg

Received 15 October, 2020

Accepted 27 January, 2021

أزمنة متعاقبة. أما المرحلة الثانية فكانت عبارة عن إجراء

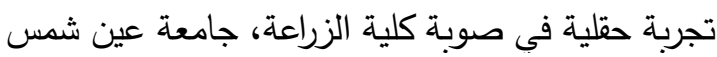

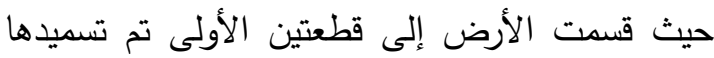

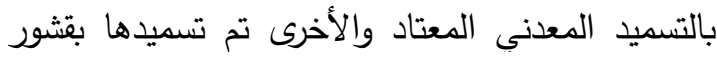

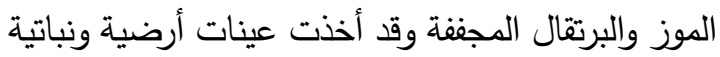

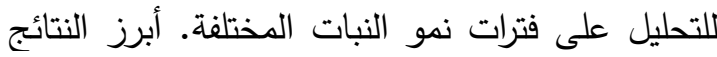

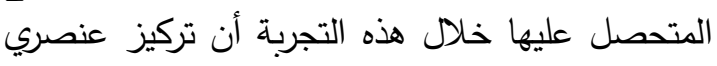

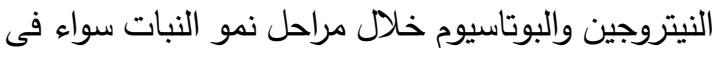

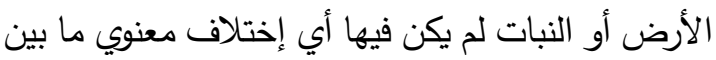

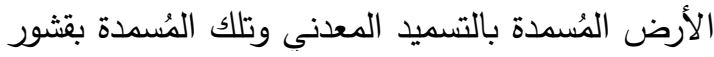

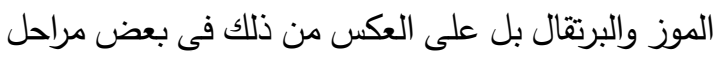

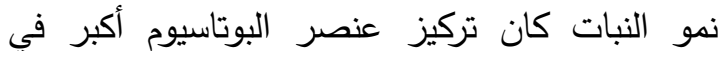

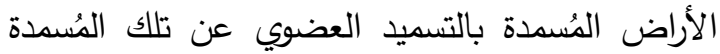

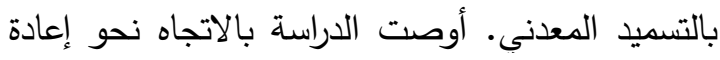

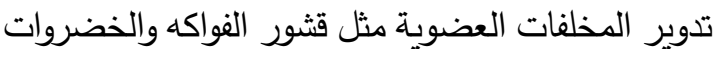

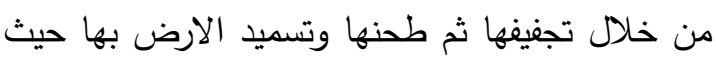

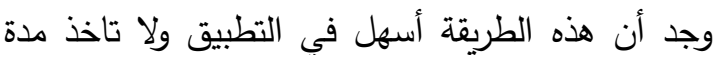

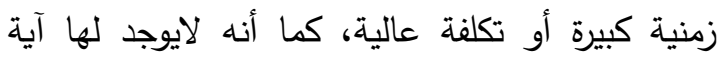

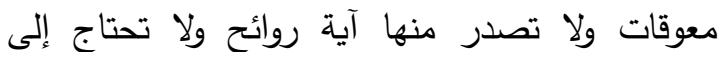

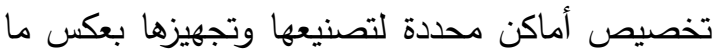

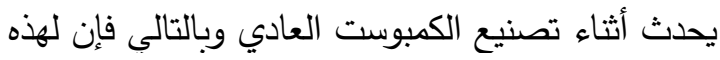
الطريقة أهمية بيئية وإقتصادية عالية.

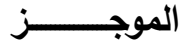

الهدف الأساسي من هذا البحث هو تعزيز إستخدام المخلفات الناتجة من عمليات التصنيع الغذائي المختلفة

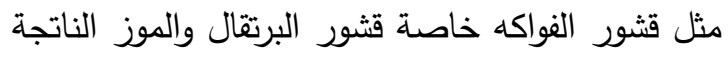

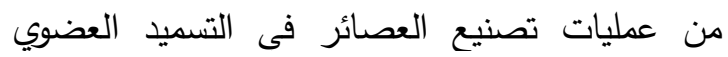

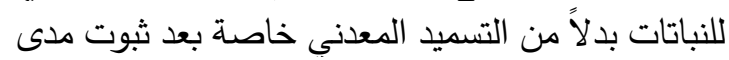
غنى هذه القشور بالعناصر الغذائية الأساسية والضرورية لإنية

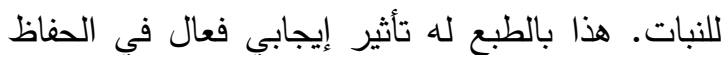

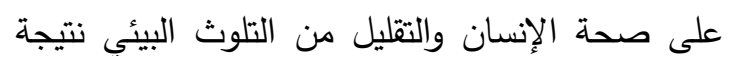

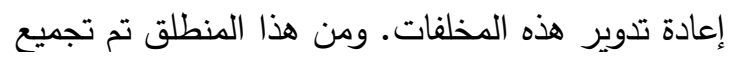

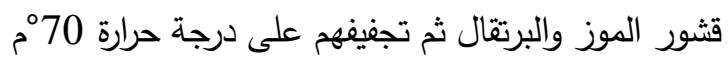

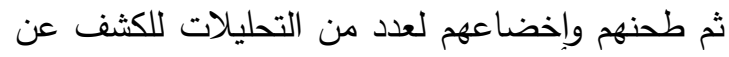

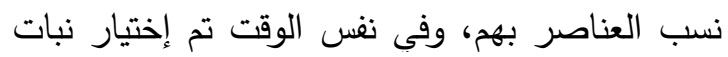

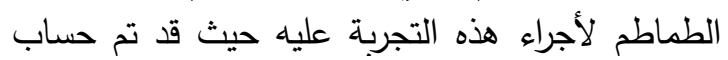

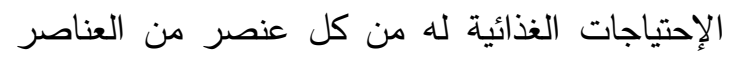

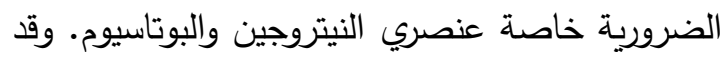

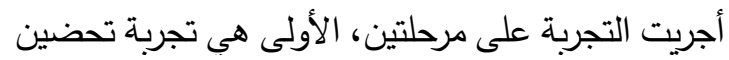

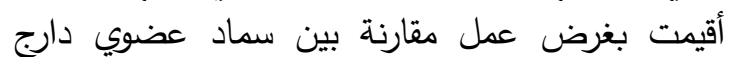

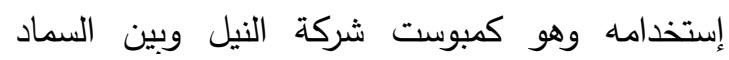

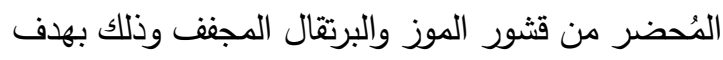
تتبع تركيزات عنصري النيتروجين والبوتاسيوم على عدة الجنقات 